\title{
Bireyve
}

Toplum

\section{Gezi Parkı Hadisesinin Anatomisi}

\section{Gökhan TUNCEL ${ }^{1}$}

Öz: Ortaya çıktığı mekândan adını alan ve kısa süre içerisinde ülke gündemini meşgul edecek bir harekete dönüşen Gezi Parkı Hadisesi, neden ve sonuçları farklı boyutlarda ele alınması gerekli bir süreç olmuştur. Gezi Hadisesi, ülkedeki devlet - toplum ile iktidar - muhalefet ilişkisinin durumunu ortaya koyan bir süreç olmanın yanında yerel, ulusal ve uluslararası aktörlerin girdiği farklı mekânsal ilişkileri de içinde barındıran bir süreç olmuştur. Karmaşık bir ilişkiler ağı üzerinden yürüyen sürecin ekonomik, siyasal, sosyal, kültürel ve çevresel boyutta, yapısal ve fonksiyonel açıdan derinlemesine irdelenmesi Gezi Hadisesinin daha anlaşılır olmasına katkı sunacaktır. Bu çalışma, değişik toplum kesimleri tarafından farklı bir anlam yüklenen ve farklı bir adlandırmaya tabi tutulan Gezi Hadisesinin yapısal düzeyde analiz edilmesini ve anatomik yapısını çıkartılmasını amaçlamaktadır.

Anahtar Kelimeler: Siyaset, katılımcılık, iktidar, muhalefet, toplumsal hareketler.

\section{Giriş}

Türkiye gibi, devletin asli belirleyici olduğu ülkelerde siyaset, toplumdaki maddi ve manevi kaynakların belli bir otoriteye bağlı olarak dağıtım sürecine karşılık gelmektedir. Doğal çevrenin korunması amacıyla başlayan ve özgürlüklerin korunması iddiasıyla etki alanını genişleten Gezi Parkı Hadisesi de aslında birçok yönüyle siyasetin bu tanımına

1 Yrd. Doç. Dr, İnönü Üniversitesi İİBF Siyaset Bilimi ve Kamu Yönetimi:gokhan. tuncel@inonu.edu.tr 
karşllık gelmektedir. Türkiye, devletin ekonomik, siyasal, sosyal ve kültürel alanda asli belirleyici olduğu bir ülkedir. Bu durum ülkede ortaya çıkan ekonomik, sosyal, kültürel, dini ve çevresel hak taleplerinin ve hareketlerin siyasala dönüşmesine veya siyasal gibi algılanmasına neden olabilmektedir. Türkiye'de devletin güç ve imkânlarını uzun yıllar kullanan bürokratik seçkinci kesim, demokratik anlamda kabul edilebilir bir siyasal alan oluşumunu engellediği gibi, toplumsal düzeyde ortaya çıkan hak taleplerini de kendi iktidarına yönelik bir tehdit olarak alg1lamıştır. Devletin güç ve imkânlarını kullanan seçkinci kesimin siyasal iktidarı elde ederken ve kullanırken geniş bir toplumsal desteğe dayanmamış olması, ülkede süreklilik arz eden devlet toplum gerilimini ortaya çıkarmıştır. Siyasal iktidarın ülkedeki belirleyici gücü ile devlettoplum gerilimi, ülkede sivil toplum alanın gelişmesine ve genişlemesine engel olmuştur. Oysa, demokratik bir sistemin ortaya çıkması ve gelişmesi sivil toplumun gelişmişliği ve etkililiğiyle doğrudan bağlantılıdır.

Türkiye'de burjuva devriminin yaşanmamış olması, toplumsal ve siyasal düzeyde etkili bir sınıfsal ayrışmanın ortaya çıkmasını engellemiştir. Sınıfsal ayrışma eksikliği, demokratik sistemin istikrarlı bir şekilde sürdürülebilirliğini sağlayacak siyasal kurumların toplumsal düzeyden (tabandan) gelişimini engellediği gibi bu kurumların seçkinci kesim tarafından kurulmasına ve kontrol edilmesine zemin hazırlamıştır. Ayrıca, temsili demokrasinin asli unsurları olan seçim, parlamento ve siyasi partiler, devlet seçkinleri tarafından çoğu zaman işlevsizleştirme ve itibarsızlaştırma girişimlerine maruz kaldığı için siyasal sistem üzerinde uzunca bir süre etkili olamamıştır.

Türkiye'de devletin belirleyiciliği dışında özerk ve geniş sivil bir alanın ortaya çık(a)mamış olması, ülkede siyaset ve iktidar değişiminin, Batıda olduğundan farklı, hayati bir anlam taşımasını beraberinde getirmiştir. Bu manada Türkiye'de iktidar sahiplerinin iktidarını koruması ve iktidar değişiminin demokratik aracı seçimler adeta bir ölüm kalım savaşı niteliği taşımaktadır. Tarihsel süreç içerisinde çevrenin temsilini üstlendiği iddiasında olan siyasal seçkinci blok, seçimin merkeze alındığ 1 demokratik bir sürece vurgu yaparken, bürokratik seçkinci kesim ise devlet aklının merkeze alındığı bir sisteme vurgu yaparak iktidarını 
koruma ve güçlendirme eğiliminde olmuştur. Bu durum, Türkiye'de siyasetin iktidar sahipleri için korku ve endişe üzerinden yürümesine neden olmuştur. Öyle ki, bu korku ve endişe bürokratik seçkinci bloğu, iktidarının devamı için seçimler de dahil hemen hemen bütün demokratik girişim ve oluşumları sürekli baskı altında tutma girişimine yönlendirirken, seçimin merkeze alındığı siyaset yaklaşımını benimseyen siyasal seçkincilerin ise, kendisine muhalif olan veya öyle algıladığ 1 kurum ve kesimlerden gelen her türlü demokratik girişim ve oluşumu kendi iktidarına yönelik bir tehdit olarak görmesine zemin hazırlamıştır.

Türkiye'de geçmişte yaşanan siyasal birçok süreç gibi Gezi Hadisesine de değişik toplum kesimleri ile iktidar ve muhalefet farklı bir anlam yüklemiş ve bu süreçte farkı bir yaklaşım sergilemiştir. Bu çalışmada, ülkedeki siyasal bloklaşmanın Gezi Hadisesỉnin ortaya çıkışına ve daha da önemlisi toplumsal bir karşılık bulmasına etkisi yapısal düzeyde irdelenmektedir. Bu tür hadiselerin yapısal analizi yapılmadan doğru bir şekilde açıklanabilmesi ve anlaşılabilmesi oldukça zordur.

\section{Türkiye'de Siyasal Yapı ve İşleyişi}

Türkiye' de devlet gücünü ve imkânlarını kullanarak var olan ve var olmasını bu güç ve imkânlara borçlu olan (Kösebalaban, 2008: 51) merkezdeki seçkinci kesim, bu güç ve imkânları halkla paylaşmaya pek niyetli olmamıştır. 1908'de II. Meşrutiyet'in ilanı sonrasında İttihat ve Terakki iktidarıyla kurulan siyasal yapı Cumhuriyetin ilk dönemlerinde yapısal köklü dönüşüm yaşamış olmasına karşın, iktidarı elinde tutan kesimler ve siyaset tarzı açısından büyük bir değişim geçirmemiştir. Bu süreçte yaşanan toplum devlet gerilimi, iktidar muhalefet ilişkisi veya mücadelesi üzerinden somutlaşmıştır.

1950' deki iktidar değişimi ile başlayan iktidar muhalefet ilişkisi, çevrenin kendi özellikleriyle merkeze ${ }^{2}$ yönelimi 1970’lerde Milli Görüş Hareketi’nin ortaya çıkışıyla farklı bir evreye girmiştir. 24 Ocak 1980 tarihli ekonomi kararları çevrenin önemli aktörü konumundaki

2 Siyaset bilimine E. Shills tarafından kazandırılan merkez - çevre yaklaşımını Ş. Mardin Türkiye siyasetini açıklayıcı anahtar bir yaklaşım olarak benimsemiştir, Bknz. Shills, 1975, Shils: 2002, Mardin, 2009 
muhafazakâr kesimin ekonomik, sosyal ve siyasal alanda belirleyici bir güç olmasına altyapı hazırlamıştır. Temsili demokrasinin kural ve kurumlarının işletildiği Türkiye'de muhafazakâr kesimin ülke siyasetinde etkisini artırması, varlığını devlete ve demokratik kuralların tam olarak işletilmediği bir siyasete borçlu olan seçkici kesimi rahatsız etmiştir. Muhafazakâr kesimin 1996 yılında, kendi özellikleriyle, siyasal iktidara ortak olma girişimi 28 Şubat süreci ile engellenmiştir. Ancak 1997 yılında Refah Partisỉnin iktidardan uzaklaştırılması sonrası başta ekonomi olmak üzere siyasal alanda yaşanan olumsuzluklar 2002 yılında muhafazakâr kesimin yeni temsilcisi konumundaki Ak Parti'nin tek başına iktidara gelmesini sağlamıştır. Ak Parti iktidarı ise, ülkedeki merkezçevre mücadelesinin farklı bir evreye taşınmasına zemin hazırlamıştır. Özellikle 2007 sonrasında geleneksel merkez, ülke siyaseti üzerindeki asli belirleyicilik özelliğini, çevrenin temsilcisi konumundaki seçilmiş siyasi iktidara devretmek durumunda kalmıştır.

Türkiye'nin siyasal hayatında merkezde konumlanan ve devletin imkânlarıyla var olan, varlığını koruyan ve geliştiren seçkinci kesim (Karpat, 2010: 419), siyasal iktidarın asli meşruiyet kaynağı olarak halkı görmemiştir. Ak Parti iktidarı sonrasında yaşanan hadiseler bu gerçeği bir kez daha gün yüzüne çıkmıştır. Halk iradesinin siyasal alana yansımasına aracılık eden seçimlerle iktidara gelen Ak Parti'nin, kapatılma girişimi gibi, demokratik olmayan yollarla iktidardan uzaklaştırılması girişimleri, merkezde konumlanan seçkinci kesimin demokrasiye yüklediği anlamın anlaşılması açısından oldukça önemlidir.

2002 sonrasında iktidara gelen Ak Partinin iktidarda olmasının getireceği yozlaşma ve yıpranma sürecine gireceği beklentilerinin aksine, yapılan her seçimden güçlenerek çıkması ve iktidarını sağlamlaştırıcı yapısal düzenlemelere gitmesi, seçilmiş ve atanmış seçkinci kesimin, eskiden kalma alışkanlıkları olan, demokrasi dışı yöntemlere yönelmesini berberinde getirmiştir. Ak Parti ile mücadelede kullanılan demokrasi dışı yöntemlerin de başarısızlıkla sonuçlanması ülkedeki seçkinci kesim başta olmak üzere muhalefetin ümitsizliğe düşmesine neden olmuştur. Demokratik sistemlerde yapısal muhalefetin asli unsurları olan muhalefet partilerine yönelik toplum nezdindeki iktidar alternatifi olabilecek bir potansiyel taşımadığı algısı, devletin kaynak dağıtımında asli belirleyici konumda bulunduğu Türkiye'de siyasal alanda hızlı bir gerilim ve 
kutuplaşma yaşanmasına zemin hazırlamıştır. Ülkede ortaya çıkan bu gerilim ve kutuplaşma yapısal muhalefet ümitsizliğine ${ }^{3}$ neden olduğu gibi şiddet eğilimli veya şiddete yönelim potansiyeli taşıyan eylem ve oluşumları beslemesi de söz konusudur. Ayrıca, ülkede oluşturulmaya çalışılan bu gerilim ve kutuplaşma ortamı bir taraftan yapısal muhalefet dışı oluşum ve hareketleri beslerken, diğer taraftan bu tür oluşum ve hareketler de, ülkedeki gerilim ve kutuplaşmanın derinleşmesine ortam hazırlamıştır. Bu dönemde ortaya çıkan ve uluslararası ölçekte bir etkiye sahip olan devrimsel hareketlilik, Türkiye'deki iktidar karşıtları için ${ }^{4}$ iktidarı devirme hususunda yeni bir ümit ışığı işlevi görmüştür.

\section{Gezi Hadisesinin Yapısal Analizi}

Sosyal ve siyasal hadiselerin daha anlaşılır olabilmesi için neden, süreç ve sonuçlarının yapısal analizinin yapılması gerekmektedir. Bu açıdan bakıldığında Gezi Hadisesi’nin başlangıcı, büyükşehir belediyesi tarafından İstanbul Gezi Parkı için hazırlanan bir proje uygulamasının protesto edilmesine dayanmaktadır. Bu proje kapsamında parktaki bazı ağaçların kesilmesi veya sökülmesinin yeşile ve çevreye yönelen bir tehdit algısı üzerinden bazı insanların projeye ve proje uygulayıcısı idareye tepki göstermesi, hadiseyi başlatmıştır. Ancak, bu tür bir yerel hadisenin ulusal hatta küresel alana taşması veya taşınmasının anlaşılabilmesi, yapısal bazı analizlerin yapılmasını gerekli kılmaktadır (Sarıbay, 2013).

Devletin $^{5}$ asli belirleyici konumu Türkiye'de hemen her hadisenin kapsamı ve muhtevası ne olursa olsun ulusal düzeye taşınmasına ve iktidar mücadelesinin bir aracı olarak kullanılmasına neden olmuştur. Cumhuriyet tarihi boyunca iktidarı elinde bulunduran kesim, iktidarını

3 Muhalefet patilerindeki ümitsizliğin iki yönü bulunmaktadır. Muhalefet partileri seçmene ümit verme yetisine sahip olmadığı gibi, bunun doğal bir sonucu olarak, iktidar olma veya iktidara ortak olma ümidi de taşımamaktadır.

4 Gezi tipi hareketlilikler, Türkiye'de sol akım gençliğinin romantik devrimci düşüncesini gerçekleştireceği ortamlar olarak görülmüştür. Ancak bu defa yapısal muhalefet içersinde önemli bir konuma sahip ana muhalefet partisi, demokratik olmayan bir yolla da olsa, iktidarın devrilmesine açıkça destek olmuştur.

5 Buradaki devlet kavramı, ülkede güçlü bir merkezi idarenin varlığına karşın sivil alan ile yerelin güçsüzlüğü ve güdümlülüğüne içkindir. 
koruyabilmek için önceliği değişmekle beraber ülkede iç düşman algısı oluşturma çabası içerisinde olmuştur. Bu algı üzerinden iktidarına yönelen muhalif düşünce ve oluşumları bertaraf etmeye çalışmıştır (Kalaycıoğlu, 1998: 39). Muhalefetin bertaraf edilme süreci, çoğu zaman muhteva itibariyle siyasal olmayan unsurlar üzerinden yürütülmüştür. Aynı zamanda mekânsal olarak birbirleriyle bağlantısı olsun veya olmasın yerel birçok hadise genele teşmil edilerek muhalefet baskılanmış veya bertaraf edilmiştir. Bu süreçte temel insan hakkı olan yaşama hakkı başta olmak üzere birçok alanda insan hakkı ihlalleri yaşandığg gibi temsili demokrasinin asli kuralları hiçe sayılmıştır. Türkiye, demokratik toplumlar için olağandışı kabul edilen bu tür olumsuzlukların olağanlaştığ

2002 sonrası Ak Parti iktidarı döneminde temsili demokrasi düşüncesi, kural ve kurumları üzerinden siyaseten başarısız ${ }^{6}$ olan siyasetçiler başta olmak üzere devletin güç ve imkânlarını başkalarıyla paylaşma eğiliminde olmayan kesimlerin, özgürlük alanının daraltıldığı, insan hakları ihlallerinin olabildiğince arttığı algısı üzerinden, ülkede korku ve endişe ortamı oluşturma gayreti içerisinde olduğu gözlerden kaçmamaktadır. Türkiye' de devletin güçlü ve belirleyici konumu sınıfsal açıdan bakıldığında çıkarları çatışması gereken kesimlerin çoğu zaman aynı safta, birlikte hareket etmesini sağlamıştır. Gezi hadisesi ve sonrasında yaşanan süreçte varlığını devlete borçlu olan burjuvazi ile marjinalinden merkez soluna kadar birçok sol örgütün birlikte hareket ettiği gözlenmiştir. Diğer taraftan küresel sermayeyi ve emperyalizmi, propagandasının merkezine alan ulusalcılar ile küresel sermayenin ekonomik ve siyasal unsurlarından oluşan bir koalisyonun da Ak Parti iktidarına karşı gerektiğinde birlikte mücadele verdiği gözlerden kaçmamıştır.

Devletin imkânlarıyla var olan ve varlığını sürdürülebilir kılan kesimlerin 2002 sonrasındaki mevzi kayıplarındaki süreklilik, iktidar karşıtlı̆̆ına yönelik muhalif bir birikimin oluşmasına zemin hazırlamıştır.

6 Burada başarı kavramı, Mackyavelist bir yaklaşımla, iktidara gelme veya iktidara ortak olma ile iktidarda kalma durumu için kullanılmıştır. Bu anlamda bir başarı yaklaşımı içinde olmadıkları için, muhalefet partileri ve bu partinin liderleri yenilgiyle ayrıldıkları her seçim sonrasında değişik kriterlerle kendilerini başarılı göstermenin yolunu bulmuş ve görevlerine devam etmişlerdir. 
Ülke siyasetinde asli belirleyici unsurun seçilmişlerden daha ziyade atanmışların etkili olduğu gerçeği, bu birikimin daha bir etkili olmasını veya öyle algılanmasını beraberinde getirmiştir. Varlık kaynağı olan devlet imkânlarının elinden kaydığının farkında olan kesimlerin, Ak Parti iktidarına yönelen muhalefete hayati bir anlam yüklemesi ülkede gerilim siyasetini derinleştirmiştir. Ak Parti, on bir yıldır iktidarda olmasına karşın, iktidarının sağlam bir zemine oturabileceği örgütlü toplumsal bir yapının olmadığının farkında olduğundan, çoğu zaman iktidarını koruma güdüsüyle hareket etmek durumunda kalmıştır. Ülkedeki muhalif hemen her hareketi kendi iktidarını sonlandırma ve güçsüzleştirme girişimi olarak algılamış, yorumlamış ve değerlendirmiştir. Bu tür bir yönelim de Ak Parti iktidarını, diğer birçok hadisede olduğu gibi Gezi'de de orantısız güç kullanımına yöneltmiş ve bu yönelim de siyasal alanda şiddet potansiyeli taşıyan yeni alanların açılmasına ve şiddet sarmalının ortaya çıkmasına neden olmuştur.

Türkiye'de dini, sosyal ve siyasal alanın olabildiğince dışında tutma iddiasındaki laiklik anlayışının çarpık uygulamaları ve özellikle sağ siyasetin Sünni İslam merkezli yaklaşımı ülkedeki alevi kesimin dışlanmışlık hissine kapılmasına ve potansiyel bir muhalefet kaynağı oluşumuna zemin hazırlamıştır. Yapısal muhalefet ümitsizliği de, devlet imkânlarından yeterince faydalandırılmadığı düşüncesine sahip, alevi kesimin iktidar karşıtı her tür muhalif oluşuma destek olmasına neden olmuştur. Gezi Hadisesi’nin ulusal düzeye taşınmasında ülkedeki alevi kesimin etkisi yadsınamaz bir gerçektir.

Ak Parti iktidarının ilk yıllarının da dâhil edildiği geçmiş dönemde, ülke politikasının genel hatlarının belirlenmesinde, karar alma ve uygulama süreçlerinde belirleyici olan bürokratik seçkinci kesim ile, bu kesimin siyasal alandaki temsilcisi konumundaki CHP iktidarını tedrici olarak kaybetmiştir. Bu süreçte, gücünü kaybeden toplum kesimleri, yapısal siyasette başarılı olamayacaklarını içselleştirmişlerdir. İçinde bulundukları açmazdan çıkmalarını sağlayacak bürokratik kurumların da, seçilmiş siyasi iktidarın etkisi altına girmesi, bu kesimi iyiden iyiye ümitsizliğe düşürmüştür. Gezi Hadisesi, daha önce siyasete ilgi duyma gereksinimi duymayan bu seçkinci kesimin çocukları olan gençlerin 
siyasete yönelmelerini sağlamıştır. Gençlerin bu yönelimi siyaseten açmazda olan seçkinci kesim tarafından hararetle desteklenmeye başlamıştır. Bu süreçte güvenlik güçlerinin kullanılan orantısız güç kullanımı ve özellikle Başbakan'ın sert üslubu bu desteği daha anlamlı bir hale getirmiştir. Aslında bir bakıma bu destek, geleneksel merkezin siyaseten kendi başarısızlıklarını, gençler eliyle örtebilme çabası olarak okunabilir.

Ülkede seçilmiş siyasal iktidar aracılı̆̆ıyla, çevrenin merkeze taşınması yeni bir sorun alanın daha ortaya çıkmasına neden olmuştur. Çevrenin temsilcisi konumunda bulunan siyasetçilerin yerel ve merkezi yönetimin karar alma ve uygulama süreçlerinde belirleyici olmaya başlaması ve yönetimde katılımcılığa olabildiğince kapalı olan, eski tarzın sürdürülmesi, ülkedeki eğitimli üst gelir grubunun iktidar karşıtı konumlanmasına zemin hazırlamıştır. Çünkü, bu eğitimli grup kendi birikim ve deneyimi ile seçilmiş siyasal iktidar sahiplerinin durumunu elitist bir yaklaşımla kıyaslayınca karar alma ve uygulama süreçlerinde belirleyici olmanın kendi doğal hakları olduğunu düşünmekten kendilerini alıkoyamamaktadır. Oysa, karar alma süreçlerinde kendilerine de söz hakkı verilmesini isteyen bu kesim, geçmişte çevrenin kamu imkânlarından yararlanması ve karar alma süreçlerine katılımı bir yana, çevresel unsurların inkârı, dışlanması, baskı altına alınması ve asimilasyonu üzerinden yürüyen bir sistem olduğu gerçeği yokmuş gibi davranmaktan da geri durmamıştır.

Ülkede serbest piyasa koşullarında üretim yaparak güçlenen bir sermayenin olmaması, devletin toplum üzerindeki belirleyiciliğin artırdığı gibi, ekonominin kendi kuralları ve dinamikleri üzerinden yürümesini de engellemiştir. Ekonomik alan üzerinde siyasetin belirleyiciliği, ekonomik olanın siyasallaşmasına neden olduğu gibi sosyal ve siyasal olanın da ekonomi üzerindeki etkisini olabildiğince artırmıştır. Varlığını aldığg siyasal konumun sunduğu imkânlara borçlu olan devletçi sermaye, Gezi Hadisesi’nde ikili oynamak durumunda kalmıştır. Bir taraftan, devletin imkânlarını başkalarıyla paylaşmak durumunda olmadığı devletçi yapının devamı için, seçilmiş siyasi iktidarın devrilmesi için gezicilere gizli destek verirken, diğer taraftan seçilmiş siyasal 
iktidara olan desteğini sürdürmekte olduğunu her platformda beyan etmeye çalışmıştır.

Zamanın daralmasını ve mekânın sıkışmasını beraberinde getiren küreselleşme süreci, yerel ve ulusal alanda ortaya çıan hadiselerin uluslararası alana taşınmasına zemin hazırlamaktadır. Gezi Hadisesi de medyanın ve özellikle sosyal medyanın aktif kullanımı sayesinde kısa süre içerisinde uluslararası bir boyuta taşınmıştır. Türkiye'deki siyasal iktidardan memnuniyetsiz olan küresel sistemin etkili aktörleri, Gezi Hadisesi üzerinden ülkenin siyasal ve ekonomik istikrarsizlığa sürüklenmesi için yoğun bir çaba içerisinde girmiştir. Uluslararası sistemin ülke siyaseti üzerindeki etkisinin farkında olan iktidar karşıtı bazı muhalif yapı ve oluşumlar da, hadisenin uluslararası boyuta taşınarak, iktidarın uluslararası düzeydeki meşruiyet zemininin kayması için özel bir gayret sarf etmiştir.

Ülkenin sahip olduğu maddi ve manevi kaynakların, bir otoriteye bağlı olarak dağıtım sürecini ifade eden siyaset, devletin toplum üzerinde asli belirleyici güç olduğu Türkiye gibi ülkelerde, farklı bir anlam ifade etmektedir. Bu açıdan bakıldığında siyasetin bu dağıtım sürecinin yapı ve işletimini nasıl yaptığı, ülkenin en önemli meselelerinden biri haline gelmektedir. Geniş ve özerk bir sivil alanın gelişmemiş olması devlet imkânlarının kullanımında katılımcığı daha bir önemli kılmaktadır. Özellikle görmezden gelinen, yok sayılan, dışlanan veya bu hislere sahip olan toplumsal kesimler, katılımcılığın merkeze alınmadığı siyasal yapıya şüpheyle yaklaşma eğiliminde olmuşlardır. Gezi Hadisesi gibi toplumsal hareketler bu toplum kesimleri için bir çıkış yolu gibi görünmektedir. Ancak, yapısal siyasete karşı muhalif duruş, siyasal amaçları için şiddeti araç olarak kullanan radikal oluşum ve örgütlerin bu kesimin gençlerinden insan kaynağ 1 devşirmesine de zemin hazırlamaktadır.

\section{Gezi Hadisesi'nin Siyasal ve Sosyal Hayata Yansımaları}

Türkiye'de tek tipleştirici özelliği ağır basan uluslaşma süreci toplumdaki farklılıklar yok edilmeye, dışlamaya, yok saymaya, baskı altına almaya ve asimile etmeye çalışllarak sürdürülmüştür. Ancak, toplumdaki 
farklılıkları yok etmek üzerinden yürütülen bu süreç, toplumdaki farklılıklara neden olan ayrışma kaynaklarının ortadan kalkmasını sağlamak yerine sadece üzerini örtebilmiştir. Zaman içerisinde çeşitli vesilelerle bu örtünün kalktığı ve uluslaşma sürecinin tek tipleştirme amacına ulaşamadığı anlaşılmıştır. Uluslararası sistemde meydana gelen gelişmeler, bu örtünün kalkmasında asli belirleyici olurken, ülke içindeki bazı gelişmelerin de zaman zaman bu örtünün kalkmasına neden olduğu gözlenmiştir. Gezi Hadisesi de, ülkedeki toplumsal ayrışma kaynaklarının görünürlüğüne aracılık eden gelişmelerden birisi olmuştur.

Başlangıcını insanların sahip olduğu çevre duyarlılığından alan Gezi Hadisesi'nin, siyasala evirilmesi ve mekânsal olarak etki alanını genişletmesi ülkede var olan toplumsal ayrışma kaynaklarının aktifleşmesiyle doğrudan bağlantılıdır. Yeşilin korunması amacıyla başlayan bir hareketin ülkenin önemli projelerinin iptali ve bazı siyasetçiler ile bürokratların görevden alınmasını da içeren taleplerle muhtevasını genişletmesi, sosyal ve siyasal alanda birçok etki yapmıştır. Ayrıca yerel bir hadisenin genişleyen mekânsal etkisinin de birçok yansıması olmuştur.

Gezi Hadisesi’nin ortaya çıktıktan kısa bir süre sonra İstanbul başta olmak üzere ülkenin birçok kentinde toplumsal bir karşılık bulması ve iletişim kanalları üzerinden yürütülen spekülatif algı operasyonları, siyasal iktidarın bocalamasına ve endişelenmesine ${ }^{7}$ neden olmuştur. $\mathrm{Bu}$ hadise ülke siyasetinin, yapısal düzeyden daha çok kişisel özellikler üzerinden yürüdügüünün göstergesi olması açısından ayrıca önemlidir. Orantısız kullanılan devlet şiddetinin (Candemir, İzmir, 2013: 12) toplumsal bir karşılık bulmasına ve siyasal iktidarı zor durumda bırakmasına aracılık ettiği hadisenin radikal yapılanmalar ile terör örgütleri üzerinden marjinalize edilmesinin sağlanması siyasal iktidarın rahatlamasına neden olmuştur. Ayrıca kutuplaşma siyasetinin avantajlarını iyi kullanan Ak Parti iktidarı, başta bocalar gibi görünse de Başbakanın devreye girmesiyle, bu hadiseyi de temsili siyaset açısından kendi lehine çevirmesini bilmiştir. Temsili siyaset açısından başarılı görünse de, uzun bir

7 Başbakan dışındaki siyasilerin bütünü için bu bocalama ve endişelenme durumundan bahsedilebilir. 
tarihi geçmişi olan toplumdaki kutuplaşmanın derinleşmesine ve iktidar karşıtlığının daha keskinleşmesine zemin hazırladığı gözlenmiştir.

Yapısal siyaset veya sivil oluşumlar üzerinden ülke siyasetine etki edemeyen geleneksel seçkinci kesimin bu tür hadiselerde manipülasyona olabildiğince açık bir potansiyele sahip olduğu ortaya çıkmıştır. Özellikle uluslararası medya ve sosyal medya kullanılarak oluşturulan bilgi kirliliği ve algı yönlendirmesinden etkilenen bu kesim, aynı zamanda bu mecralar üzerinden siyasal istikrarsızlaşma operasyonları yürütme gayreti içinde olmuştur. Kutuplaşma siyasetindeki konumlanmaları, eylem ve söylemleri ülkedeki sivil toplum kuruluşlarının siyaset karşısındaki güçsüzlügünü ve özerkleşememe durumunu açıç̧a ortaya koymuştur.

Gezi Hadisesi'nin Ak Parti karşıtlarına yansımalarının yanın da, Ak Parti ve temsil ettiği toplumsal kesime yönelik önemli yansımaları da olmuştur. On yılı aşan geçmişinde, Ak Parti iktidarının güçlenmesinde ve daha da önemlisi gücünü korumasında, gerilim ve kutuplaşma siyasetinin önemli bir rolü olmuştur. Bu süreçte Ak Parti ve temsil ettiği toplumsal kesimin yaşaması muhtemel aşınma ve rehaveti ortadan kaldıran olağandışı gelişmeler olmuştur. Gezi hadisesi de Ak Parti ve temsil ettiği kesimin yeniden kenetlenmesine ve dinamizm kazanmasına aracılık eden faktörlerden birisi olmuştur.

\section{Gezi Hadisesi'nin Açmazları}

Türkiye'de siyasetin belirleyiciliği dışında kalabilecek sivil bir alanın gelişmemesi, tahakküme dayalı bir siyasal sistemin kurulmasına ve sürdürülebilir olmasına neden olmuştur. Halkın içerisine çok fazla dahil edilmediği, halkçılık ilkesi üzerinden işletilen ve merkezinde bürokratik seçkinci kesimin bulunduğu demokratik(!) sistem, uzun bir süre azınlığın çoğunluk üzerindeki tahakkümünü sağlamıştır. Ancak, bu yapı 1950 sonrasında başlayan süreçle aşınmaya başlamış ve bu aşınma istikrarlı bir süreç izlemese de ,2000 sonrasında ülke siyasetinin farklı bir evreye girmesine zemin hazırlamıştır. 2007 yılında cumhurbaşkanlığındaki değişim, geçmişteki azınlığın çoğunluk üzerinde kurduğu tahakkümün tersine dönmesine neden olmuştur. İktidarın el değiştirmesi 
sistemin değiştiği anlamına gelmediği için, çoğunluğun azınlık üzerinde tahakküm kurma sorunu veya algısı ortaya çıkmaya başlamıştır. Geçmiş alışkanlıklarını kolay kolay terk etmeyen bürokratik seçkinci kesim ve onun siyasi temsilcileri, demokratik talepler yerine, seçilmiş siyasal iktidarın meşruiyetini sorgulamaktan kendilerini alıkoyamamışlardır. Özellikle ülke siyasal sisteminin anahtar konumunda olan, cumhurbaşkanlığı makamının çevrenin özelliklerini taşıyan birisine teslim edilmesinin mümkün olamayacağını savunmuşlardır. Demokratik olmayan ve dışlayıcı bir düşünce üzerinden siyaset yürütülmesi, ülkedeki hemen her sorunun demokratik olmayan bir düzleme evirilmesini beraberinde getirmiştir. Gezi Hadisesi'nde de gayet masum ve demokratik bir talep, iktidarın meşruiyetinin tartışıldığı bir sürece evrilmiştir. Bu tür evrilmeler ülke siyasetinin demokratikleşmesine engel olduğu gibi temsili demokrasinin yara almasına ve toplumsal düzeyde kutuplaşmanın derinleşmesine etki etmektedir.

Gezi hadisesine katılan gençlerin çoğu aynı zamanda, liderinin şahsında Ak Parti’nin temsil ettiği toplum kesimine karşı ebeveynlerin yürüttügü başarısız mücadele yöntemlerine (Benhabib, 2013) bir alternatif geliştirdiği gibi, iktidar karşısında çaresizlik ve ümitsizlik yaşayan muhalefete de bir soluk aldırmıştır. Ancak temsili demokrasinin temel taşı kurumlarından siyasi parti ve parlamentonun, bu tür muhalif hareketleri merkeze alarak siyasetini yürütmesi, uzun vadede temsili demokrasinin kural ve kurumlarını işlevsizleştirme çabalarına destek verme ve dolayısıyla kendini inkâr anlamına gelecektir.

Devletin toplum üzerindeki gücü ve belirleyiciliği, birçok hadisede olduğu gibi Gezi Hadisesi’nde de, marjinal toplum kesimleri haricindeki varlıklı kesimin de içinde bulunduğu birçok yapının siyasal iktidara açıktan tavır almak yerine mücadelelerini perde gerisinde kalarak sürdürmeyi yeğlemesine neden olmuştur. Para, statü, itibar sahipleri yani, kaybedecek bir şeyleri olan insanların, temsili demokrasi kural ve kurumlarının işletilmediği devrimsel hareketlerde sürdürülebilir bir şekilde yer alması ve uzun vadede etkili olması beklenir bir durum değildir. Varlığını devlete borçlu olan, ülkedeki seçkinci kesimin, devlet 
imkânlarını eskisi kadar etkili kullanması mümkün değilse de hâlâ kaybedeceği birçok şeyleri olduğu için, gösterilerde doğrudan ve sürdürülebilir bir şekilde bulunmaları oldukça zor görünmektedir.

Kaybedeceği bir şeylere sahip olan, eğitimli orta ve üst gelir grup ve bu grubun gençlerinden sürdürülebilir ve başarıya ulaşabilir devrimsel bir siyaset beklemek yanlış olur. Ancak Türkiye'de sol kesim aydınların birçoğu bu yanlışa düşmekte veya açmazda olduğu için bu yanlışın ısrarlı savunusunu yapmaktadır. Oysa, devrimsel hareketlerin sürdürülebilirliği, kaybedeceği çok bir şeyi olmayan ve buna mukabil kazanabileceği çok şeyler olacağı hayalini taşıyan kitlelerin varlığına bağlıdır.

Serbest piyasa koşulları üzerinden yürüyen rekabetçi bir ekonominin olmadığı bir ortamda, hakkını alabilecek ve gerektiğinde siyasal iktidarın karşısında durabilecek sivil bir yapılanmanın oluşması çok mümkün değildir. Varlığını siyasal iktidara olan yakınlığına dayandırmayan ve gerektiğinde siyasal iktidarın karşısında durabilecek bir güce sahip sivil oluşum, hemen her aşamada katılımcı bir yönetimi beraberinde getirecektir. Bu nedenle Türkiye'de devletin toplum üzerindeki belirleyiciliğinin azalması, siyasetin normalleşmesi ve katılımcı bir yönetim sisteminin kurulup işletilmesi için serbest piyasa koşullarının işletilmesi gereklidir. Bu tür bir sistem kurulmadı̆̆ sürece ülkede siyaset kurumu rant dağıtmaya ve toplum üzerinde asli belirleyici olma özelliği taşımaya devam edecektir. Siyasetin bu konumu da, ülkedeki hemen her hadisenin muhteva ve mekân değişimi yaşamasına zemin hazırlayacaktır. İstikrasızlığın olağan olduğu bu coğrafyada devletin ve dolayısıyla da siyasetin toplum üzerindeki belirleyiciliğinin azalmasını beklemek oldukça zor ancak, imkansız değildir.

\section{Sonuç}

Devletin toplum üzerindeki asli belirleyiciliği üzerine kurulan yapı, ülke siyasetini etkilediği gibi, sosyal ve ekonomik olanın da kolayca siyasallaşmasına neden olmaktadır. Bu siyasallaşma eğilimi Gezi Hadisesi’nde de kendisini göstermiştir. Bu tür bir çarpık siyasallaşma (Tuncel, 2011: 12) sürecinin daha az yaşanması, büyük ölçüde bireyin devletle olabildiğince az karşılaşmasının sağlandığı bir sistemin kurulmasına ve 
işletilmesine bağlıdır. Gezi Hadisesi'nin ortaya çıkışı yerel ve özel bir nedene dayansa da süreç, genel olarak temsili demokrasi düşüncesi ve temsil kurumlarının eleştirisi üzerine evrilmişti. Ancak, yapılan eleştirilerin temsili demokrasiye bir alternatif sunmak bir yana, tutarsızlıklarla dolu söylemlerden ibaret olduğu gözlenmiştir. Oysa, katılımcılığı sağlayamama sorununun sadece mevcut siyasal iktidardan kaynaklanmadığı bunun bir düşünce, kültür ve sistem sorunu olduğu vurgulansa ve iktidar karşıtlarının da bu sorunun bir parçası olduğu gerçeği açık yüreklilikle ortaya konsa durum daha farklı bir mecraya yönelebilirdi. Her şeyden önce Gezi Parkı için hazırlanan projeye yönelik meşru muhalefet daha bir etkili olabileceği gibi, katılımcı yönetimin önünün açılmasına olumlu bir katkı da sunabilirdi.

Sonuçta, Gezi Hadisesi'nin kısa vadede iki kazananı ve iki kaybedeni bulunmaktadır. Kaderin cilvesine bakın ki, hadisenin iki ayrı ucunda bulunan her iki kesim içinde bir kazanan bir de kaybeden bulunmaktadır. Başbakanın şahsında Ak Parti iktidarı siyaseten bu süreçten kazançlı çıkarken, yükselen faiz oranlarının bütçeye yüklediği ağır yükü sırtlamak zorunda olan destekçileri, bu sürecin ekonomik olarak kaybedeni konumunda olmuştur. Üretmeden devlet destekli ve ranta dayalı bir sistem üzerinden büyüyen devletçi sermaye ekonomik olarak bu süreçten kazançlı çıarken, geçmiş dönemin asli siyasi belirleyicisi konumundaki bürokratik seçkinci elit ve bu kesimin siyasi temsilcileri, bu sürecin kaybedeni olmuştur. 


\section{Kaynakça}

Benhabib, Ş., 2013. Gezi Parkı Protestoları: Küresel Bağlam ve Türkiye'de Siyasetin Geleceği,http://konusakonusa.org/2013/08/25/seyla-benhabib-ile-turkiyenin-demokrasi-yolculugu-ve-gezi-olaylari-uzerine-konustuk/ (E.T. 02. 12.2013)

Candemir, Ü. S, İzmir, M., 2013. Mazlumder İstanbul Şubesi Taksim Gezi ParkıOlayları Raporu, İstanbul

Kalaycığlu, E., 1998. “27 Mayıs 1960 İhtilali’ne Giden Yol”, (ed.) S.

Kili (1998), 27 Mayıs 1960 Devrimi Kurucu Meclis ve 1961 Anayasası, İstanbul: Boyut, 33-44

Karpat, K. H., 2010.Türk Demokrasi Tarihi, İstanbul: Timaş Yayınları

Kösebalaban, H., 2008. "Merkez-Çevre İlişkileri: Türk Siyasetinin Anahtarı mı?”, Anlayış Dergisi, Sayı: 60, 50-52

Mardin, Ş., 2009. Türkiye'de Toplum ve Siyaset, Makaleler 1, 16. Basım, İstanbul: İletişim Yayınları

Sarıbay, A. Y., 2013., http://haber.stargazete.com/acikgorus/demokrasinin-yalniz-kalabaliklari/haber-766924 (E.T. 09.02.2014)

Shils, E., 1975. Center and Periphery Essays in Macrosociology, Chicago and London: University of Chicago Press

Shils, E., 2002. "Merkez-Çevre” (Çev. Y. Z. Çelikkaya), Türkiye Günlüğü, Say1: 70, .86-96.

Tuncel, G. 2011. “Siyasallaşma Sürecinde Din ve Etnisitenin Etkisi: Mardin Örneği”, Uluslararası Midyat Sempozyumu Bildiri Kitapçığı, Mardin, s.685- 702 
Abstract: - The Anatomy of Gezi Events: Gezi Events, which took its name after the place events occurred, came into agenda of the country in a short while. It is a process needs to be analysed from different dimensions. Besides being a determining process of people- state and governmentopposition relations, Gezi Park incident has also been a process by nestling local, national and international political actors a new kind of relations. To better understand "Gezi Incidence", which is going on a complex web of relations, the process needs to be analysed in social, political, economic and environmental point of view. This study aims to analyse "Gezi Incidence" on structural level and anatomic structure of the Incidence will be laid down.

Key Words: Politics, Participation, Power, Opposition, Social Movements 